\title{
MODELLING THE IMPACT OF FISCAL POLICY ON NON-OIL GDP IN A RESOURCE RICH COUNTRY: EVIDENCE FROM AZERBAIJAN
}

\author{
Khatai Aliyev ${ }^{1}$, Bruce Dehning ${ }^{2}$, Orkhan Nadirov ${ }^{3}$ \\ ${ }^{1}$ Institute for Social Sciences and Humanities, Qafqaz University, Khirdalan, Azerbaijan; Institute of Control \\ Systems, Azerbaijan National Academy of Sciences, Baku, Azerbaijan \\ ${ }^{2}$ Argyros School of Business and Economics, Chapman University, Orange, California, United States \\ ${ }^{3}$ Faculty of Management and Economics, Tomas Bata University in Zlin, Zlin, Czech Republic
}

\begin{abstract}
ALIYEV KHATAI, DEHNING BRUCE, NADIROV ORKHAN. 2016. Modelling the Impact of Fiscal Policy on Non-Oil Gdp in a Resource Rich Country: Evidence from Azerbaijan. Acta Universitatis Agriculturae et Silviculturae Mendelianae Brunensis, 64(6): 1869-1878.

This paper analyses the impact of public expenditures and tax revenues on non-oil economic growth in Azerbaijan for the period of 2000Q1-2015Q2 by employing OLS, ARDL, FMOLS, DOLS, CCR and Granger Causality techniques. Different cointegration methods result in consistent results. In this study, there is strong evidence of significant long-run positive contributions from public expenditures to non-oil sector output. Results also show that tax revenues significantly slow down non-oil economic growth in the long run. Granger Causality analysis finds the existence of a bidirectional short-run association between non-oil GDP and public expenditures, while tax revenues Granger Cause both variables. The research findings should be useful for Azerbaijan fiscal policy makers to consider now and in the future. Current plans in Azerbaijan for both public expenditure cuts and tax revenue increases are likely to cause contraction in the Azerbaijan's non-oil sector GDP.
\end{abstract}

Keywords: Non-oil GDP, public expenditures, tax revenues, fiscal contraction, Azerbaijan

\section{INTRODUCTION}

In modern times, inducing economic growth is one of the primary goals of governments. In Keynesian economic theory, public expenditures are emphasized as a key tool for governments to use to rescue economies and to increase employment in time of downward business cycles (Keynes, 1936). The effectiveness of public spending on economic growth has been widely researched in recent decades. Nevertheless, expenditures affect the sustainability of public finances through the influence on fiscal balances and government debt (Afonso and Furceri, 2010). Government size may undesirably influence economic growth. Expanding the public sector can have a negative impact on economic growth due to complications such as government inefficiencies, the excess burden of taxation, crowding-out effects, the distortion of incentives systems, and interventions in free markets (Afonso et al., 2005, 2011). Simultaneously, public expenditures may have positive contributions in terms of legal, administrative, and economic infrastructural development. Therefore, the allocation and use of budget expenditures and setting optimal tax policy should be jointly determined under the fiscal policy of a government.

Modelling fiscal policy effectiveness in resource rich economies is much more complex than in less resource rich economies. With large revenue inflows from resources, ruling parties try to attain the satisfaction of voters. The fiscal channel is perhaps the simplest way to inject easily obtained revenues into the economy. Because of this, there should be an in-depth examination and discussion of public expenditure efficiency. However, achieving and maintaining efficiency is a difficult task, severely dependent upon political-institutional factors (Tornell and Lane, 1999; Kaminsky, Reinhart and Vegh, 2005; Talvi and Vegh, 2005; Alesina, Campante and Tabellini, 2008) and the level of corruption 
(Dietz, Neumayer, and Soysa, 2007; Andersen and Aslaksen, 2008) in the corresponding country. The high price of oil paves the way for massive foreign reserve inflows followed by "generous" fiscal spending behaviour in natural resource exporters (Sturm et al., 2009; Weykman-Linn and Selm, 2002), but the excessive use of revenue from resources may turn productive expenditures into unproductive ones (Devarjan et al., 1996).

Azerbaijan, a small developing country located on the Caspian Sea in South Caucasus, has enjoyed an oil boom since 2005. This boom intensely affected the fiscal policy behaviour of the government. For example, Azerbaijan's budget expenditures in 2008 were five times the expenditures in 2005 . This expansionary fiscal tendency continued in the following years, far exceeding increases in tax revenues and mostly financed by direct transfers from The State Oil Fund of the Republic of Azerbaijan (SOFAZ). ${ }^{1}$ In addition to direct transfers from SOFAZ, non-transfer budget revenues are also partially generated by oil sector tax payments. In this context, it is expected that budget expenditures should have a strong positive impact on non-oil economic growth, which is in contrast to a minor decelerating effect of increasing tax revenues. Therefore, development of the non-oil sector should be a priority for Azerbaijan.

We contribute prior studies by incorporating the latest fiscal policy changes to our models. Rather than relying on government expenditures, we use two additional factors such as the tax-side effects of fiscal policy and the potential role of oil-related factors. Our results indicates that every $1 \%$ reduction in public expenditures lower non-oil GDP approximately $0.73-0.87 \%$ and a $1 \%$ increase in tax revenues lower non-oil GDP by around 0.36-0.49\%, holding other factors fixed. Another interesting finding in our paper is that oil-related factors has insignificant long-run impacts on the non-oil GDP.

\section{MATERIALS AND METHODS}

Following the Great Depression in the 1930s, fiscal policy as advocated by Keynes has been actively used by governments to stimulate economies. For several decades, the relationship between government expenditures and economic growth has been explored empirically (Landau, 1986; Barro, 1991; Cooray, 2009; Folster and Henrekson, 2001, among others). In this context, there are two noteworthy theoretical propositions. One is the so called "Wagner's Law", which justifies public expenditures as an endogenous factor and an outcome of national income aggregates, not as the cause of economic growth (Henrekson, 1993). Second, public expenditures, when treated as an exogenous factor, could be used for policy purposes in Keynesian propositions (Afonso and Furceri, 2010). More precisely, causality is from national income to public expenditures under the Wagner's Law framework, while the opposite through a domestic demand channel within the latter one.

While taking resource rich economies into consideration, it is noteworthy to remember the possible negative impacts of injecting resource revenues into the economy through fiscal channels, especially for developing countries. The negative impacts include weak institutional development (Sala-i-Martin and Subramanian, 2003; Gylfason, 2004), Dutch Disease (Krugman, 1987; Auty, 2001), and others. Previous studies have found lower economic growth in resource-rich countries in comparison with resource-poor ones (Sachs and Warner, 1999; Auty, 2001).

Currently, one of the most important goals for policy makers in Azerbaijan is growing the labour force in the non-oil sector by expanding the role of the private sector in the economy. The country's fiscal policy has shown overwhelming weakness due to the volatility of the price of oil. The public sector is the principal player in the economy of Azerbaijan. Auty (2001) argues that the public sector can be thought of as an engine of economic growth in oil exporting countries. In this context, it is noteworthy to review the relevant studies on fiscal policy effectiveness in similar cases.

For example, Kireyev (1998) estimated the relationship between the change in government expenditures and growth in the non-oil GDP for Saudi Arabia using a pair wise Granger causality test for a sample period 1969-97. His results indicated that 1 percent increase in total government expenditures causes a roughly 0.5 percent increase in non-oil GDP. Joharji and Starr (2010) tested the relationship between government capital and current expenditures and non-oil sector GDP in Saudi Arabia from 1969-2005 using time-series methods. Their results show that compared to capital expenditures, capital government expenditures have larger effects on non-oil GDP growth. This empirical finding was also supported by Espinoza and Senhadji (2011), who found that capital government expenditures have the largest effect on the non-oil sector.

Treichel (1999) examined the same relationship for Oman for 1981-1997, but subdividing total real government expenditures into current and capital spending. He found that an increase of 1 percent in current government expenditures may generate about a 0.6 percent increase in non-oil GDP growth,

1 The State Oil Fund of the Republic of Azerbaijan (SOFAZ) was established on December 29, 1999 by a Presidential Decree № 240 with the aim of achieving efficient management of revenues generated from the sale of natural resources and its equal distribution among generations. For more information, see: www.oilfund.az 
while an increase of 1 percent in capital government expenditures may generate only a 0.2 percent increase in non-oil GDP growth.

To the best of our knowledge, only a few studies investigate the relationship between disaggregated government expenditures and economic growth for Azerbaijan. Employing the Autoregressive Distributed Lags Bounds Testing (ADLBT) approach, Hasanov and Alirzayev (2012) investigated the impact of total budget expenditures on non-oil economic growth for the 2001Q1-2012Q4 period and found the existence of a significant positive relationship. Hasanov (2013a) also investigated this relationship by using a single equation-based, ADLBT approach. A system-based cointegration approach used by Johansen (1988) and Johansen and Juselius (1990) for the period 1998Q4-2012Q3 concluded with similar findings. While examining Dutch disease symptoms in the Azerbaijan economy, Hasanov (2013b) discovered a "spending effect" in the economy created by budget expenditures. The existence of a positive contribution of total public expenditures and/or its components is also found in Aliyev (2013) who analysed oil-exporting countries including Azerbaijan.

Although Hasanov and Alirzayev (2012) and Hasanov (2013a) examine expenditures, none of them study the tax-side effects of fiscal policy and the do not consider the potential role of oil-related factors in non-oil economic performance. This study fills both of these gaps in the literature by considering the latest fiscal policy changes.

The dataset employed for all empirical estimations covers the 2000Q1-2015Q2 period. Definition and source of the variables are presented below:

Real non-oil GDP(RGDPN), measured in millions of Manat, is the inflation-adjusted sum of value added that was produced in the economy, excluding the oil sector. Quarterly data is compiled and released by the Central Bank of Azerbaijan (CBAR) and the State Statistical Committee of Azerbaijan. The data employed in the empirical tests is from the statistical bulletins of CBAR, which can be accessed online. ${ }^{2}$

Real budget expenditures (RBE), measured in millions of Manat, is the sum of total government expenditures from the central budget, and then adjusted for inflation. Quarterly data is obtained from the CBAR database.

Real non-transfer budget revenues (RBRN), measured in millions of Manat, is the sum of budget revenues from direct transfers from SOFAZ. Quarterly total budget revenues were taken from the CBAR database. Quarterly direct transfers to the state budget were obtained from SOFAZ quarterly statements and subtracted from quarterly total budget revenues, then adjusted for inflation.

Oil production (OPrn) is the measure of Azerbaijan's quarterly average daily oil production in thousands of barrels per day. The monthly data is obtained from the Trading Economics database ${ }^{3}$ and converted to quarterly data.

Oil price $(\mathrm{OPrc})$ is the quarterly world average price of one barrel of oil taken from the index mundi database. The original monthly data was converted to quarterly data by using a simple average method.

To adjust for inflation, the Consumer Price Index (CPI) method is used. Tab. I tabulates descriptive statistics of the variables.

Based on employed quarterly real data, the time profile of the logs of the variables are provided in Fig. 1.

A linear model representing the relationship of interest is as follows, where all variables are in natural logarithms, as indicated by a leading "l" in variable names:

$\operatorname{lrg} d p n_{t}=\beta_{0}+\beta_{1} l r b e_{t}+\beta_{2} l r b r n_{t}+\beta_{3} \operatorname{loprc}_{t}+\beta_{4} \operatorname{loprn}_{t}+u_{t}$ (1)

I: Descriptive statistics of the variables

\begin{tabular}{lcccccc}
\hline \multicolumn{1}{c}{ Variable } & Obs. No. & Mean & Maximum & Minimum & Std. Dev. & Sum \\
\hline RGDPN & 62 & $1,730.5$ & $3,445.8$ & 515 & 848.1 & $107,290.2$ \\
RBE & 62 & 995 & $2,914.9$ & 141.6 & 728.6 & $61,689.8$ \\
RBRN & 62 & 566.9 & 985.5 & 149.4 & 267.7 & $35,147.5$ \\
OPrc & 62 & 64.97 & 121.1 & 19.3 & 31.3 & - \\
OPrn & 62 & 670.8 & 1,066 & 274 & 293.6 & 41,590 \\
\hline
\end{tabular}

Source: Authors' own compilation

2 Central Bank of Azerbaijan Republic regularly publishing monthly statistical bulletin of Azerbaijan economy. For more information, see: http://en.cbar.az/pages/publications-researches/statistic-bulletin/

3 Trading Economics was founded by Antonio J Fernandes Sousa and Anna Fedec in New York City, provides accurate statistical information for 196 countries. Azerbaijan's oil production records is retrieved from: http://www. tradingeconomics.com/azerbaijan/crude-oil-production/,01.10.2015. 

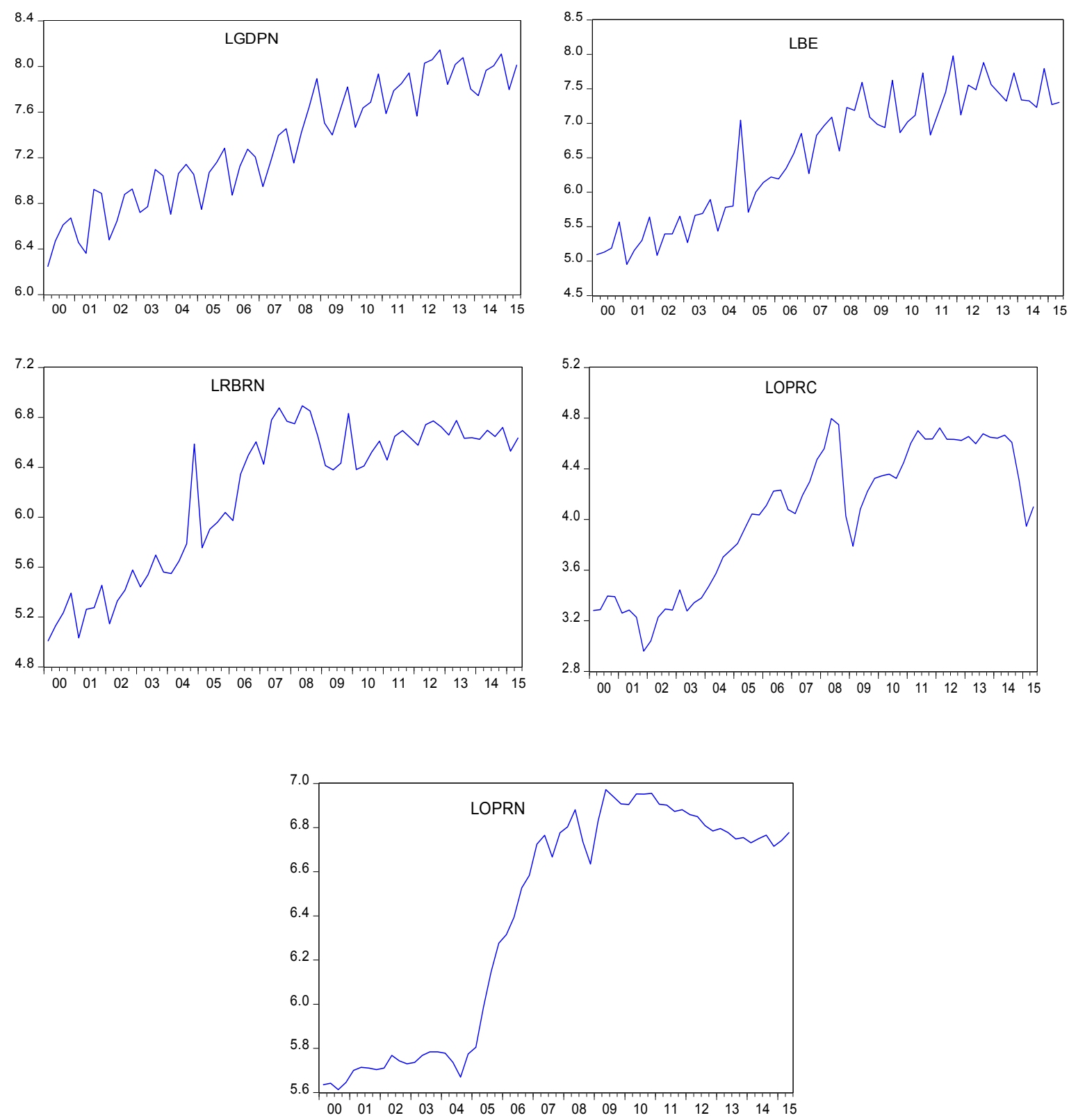

1: Time profile of the logs of variables

To reveal the direction of causality towards budget expenditures, we also run the following regression:

$l r b e_{t}=\gamma_{0}+\gamma_{1} l r g d p n_{t}+\gamma_{2} l_{l r b r n_{t}}+\gamma_{3} l_{0 p r c_{t}}+\gamma_{4} \operatorname{loprn}_{t}+\theta_{t}$

Here rgdpn, rbe and rbrn stand for non-oil GDP, total budget expenditures and non-transfer budget revenues respectively. The variables oprc and oprn are included to the model to control for the effects of oil related factors - oil price and oil production on non-oil economic performance. The intercept and coefficients of the regression are denoted by $\beta_{i}(i \in 1 \ldots 4)$, while represent model residuals. In this equation, our purpose is to estimate $\beta_{1}$ and $\beta_{2}$. The models fulfil Gauss-Markow assumptions.
Based on Keynesian economic theory and the Wagner Law hypothesis, our expectation is $\beta_{1}>0, \beta_{2}<0$, and $\gamma_{1}>0$. To check for integration order of the variables, which is important to consider while estimating cointegration equations, we employ Augmented Dickey Fuller (ADF), the Phillips-Perron (PP) and the KwiatkowskiPhillips-Schmidt-Shin (KPSS) unit root tests to enhance the robustness of the results. Note that ADF and PP tests the null hypothesis unit root while KPSS tests the null hypothesis of (trend) stationarity.

To determine reliable empirical results, we estimate the relationship of interest by employing several methods. Firstly, OLS is applied to equation (1) and (2). Next, we use error-correction models 
to investigate the direction of causality, and cointegration relationships among the variables as follows:

$$
\begin{aligned}
& \Delta l r g d p n_{t}=c_{o}^{\prime}+\sum_{i=1}^{k} \omega_{i}^{\prime} \Delta l r g d p n_{t-i} \\
& +\sum_{i=0}^{k} \varphi_{i}^{\prime} \Delta l r b e_{t-i}+\sum_{i=0}^{k} \tau_{i}^{\prime} \Delta l r b r n_{t-i} \\
& +\sum_{i=0}^{k} \gamma_{i}^{\prime} \Delta l o p r c_{t-i}+\sum_{i=0}^{k} \mu_{i}^{\prime} \Delta l r o p r n_{t-i} \\
& +\beta_{1} e c t_{t-1}+\epsilon_{t}
\end{aligned}
$$

and

$$
\begin{aligned}
& \Delta l r b e_{t}=c_{o}^{\prime}+\sum_{i=0}^{k} \varphi_{i}^{\prime \prime} \Delta l r b e_{t-i} \\
& +\sum_{i=1}^{k} \omega_{i}^{\prime \prime} \Delta l r g d p n_{t-i}+\sum_{i=0}^{k} \tau_{i}^{\prime \prime} \Delta l r b r n_{t-i} \\
& +\sum_{i=0}^{k} \gamma_{i}^{\prime \prime} \Delta l o p r c_{t-i}+\sum_{i=0}^{k} \mu_{i}^{\prime \prime} \Delta \operatorname{lroprn}_{t-i} \\
& +\beta_{2} e c t_{t-1}^{\prime}+\varepsilon_{t}
\end{aligned}
$$

Where, $e c t_{t-1}$ and $e c t_{t-1}^{\prime}$ are the one period lagged error-correction term derived from the long term co-integration relationship described in equation (1) and (2), which are explicitly defined as in equation (5) and (6) respectively:

$$
\begin{aligned}
& \text { ect } t_{t-1}=\operatorname{lrgdpn}_{t-1}-\beta_{0}-\beta_{1} \operatorname{lrbe}_{t-1} \\
& -\beta_{2} \operatorname{lrbrn}_{t-1}-\beta_{3} \operatorname{loprc}_{t-1}-\beta_{4} \operatorname{loprn}_{t-1} \\
& \text { ect }{ }_{t-1}^{\prime}=\operatorname{lrbe}_{t-1}-\gamma_{0}-\gamma_{1} \operatorname{lrg}_{\mathrm{l}} \operatorname{lpn}_{t-1} \\
& -\gamma_{2} \text { lrbrn }_{t-1}-\gamma_{3} \operatorname{loprc}_{t-1}-\gamma_{4} \operatorname{loprn}_{t-1}
\end{aligned}
$$

In equation ( 3 ) and (4), $\Delta$ means the first-difference operator and $k$ is the optimal lag length based on Schwarz-Bayesian information criteria (SBC). The error terms $\varepsilon_{t}$ and $\epsilon_{\mathrm{t}}$ are independently and normally distributed with mean zero and constant variance.

Employing equations (3) and (4), we will examine Short-run Granger causalities through testing the significance of the lagged differenced terms by either the F-statistic or Chi-squared statistic in the Wald test for each variable. For example, to examine Short-run Granger causality from lrbe to

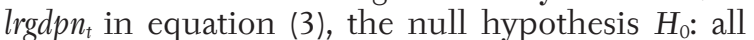
$\varphi_{i}{ }^{\prime}=0, i=0, \ldots, k$ will be tested. Rejection of the null hypothesis means the existence of Short-run Granger causality from $l r b e_{t}$ to $l r g d p n_{t}$. To test long-run Granger causalities, the statistical significance of the one period lagged error correction term (ect $t_{-1}$ and $\left.e c t_{t-1}^{\prime}\right)$ should be examined using a t-test. For example, the null hypothesis $H_{0}: \beta_{1}=0$ will be tested for non-causality from long-run equilibrium deviation to non-oil economic growth in equation (3). Strong causality requires testing short-run and long-run causalities jointly. Hence, strong causality from lrbe to $\operatorname{lrg} d p n_{t}$ in equation (3) will be tested against the null
$H_{0}: \varphi_{i}^{\prime}=0, i=0, \ldots, k$, and $\beta_{1}=0$ by using either the F-statistic or Chi-squared statistic in the Wald test.

To test the robustness of the results, four additional cointegration methods are employed to examine the long-run relationships of interest. The four methods are the Autoregressive Distributed Lag Bounds Testing (ARDLBT) approach, Fully Modified Least Squares (FMOLS), Dynamic Least Squares (DOLS) and Canonical Cointegrating Regression (CCR).

ARDLBT approach to cointegration is suggested by Pesaran and Shin (1999) and developed by Pesaran, et al. (2001). This method is preferred to alternative approaches due to its easy applicability in small samples by using OLS with all $\mathrm{I}(0)$ or $\mathrm{I}(1)$ series as well as series with a combination of the two. One more advantage of ARDLBT is the validity of estimation outputs even if some of the independent variables are endogenous. Note that equation (3) and (4) are static OLS regression models, which does not account for the endogeneity of explanatory variables. Moreover, ARDLBT enables simultaneously estimating long-run and short-run coefficients (Pesaran et al. 2001, Oteng et al. 2006, Sulaiman et al. 2010). Application of the ARDLBT approach starts with the estimation of equation (7) where $\theta_{i}, i=1, \ldots, 5$ represent the long-run impact of the corresponding explanatory variable while $\alpha_{i}$, $i=1, \ldots, m, \gamma_{i}, i=1, \ldots, n, \delta_{i}, i=1, \ldots, k, \vartheta_{i}, i=1, \ldots, p$, $\mu_{i}, i=1, \ldots, q, \pi_{i}, i=1, \ldots, 5$,and denote short-run coefficients. Here, $m, n, k, p, q$ and $r$ are optimal lag length based on Schwarz-Bayesian information criteria (SBC).

$$
\begin{aligned}
& \Delta \operatorname{lrg} d p n_{t}=c_{0}+\theta_{1} \operatorname{lrg} d p n_{t-1}+\theta_{2} \operatorname{lrbe}_{t-1} \\
& +\theta_{3} \operatorname{lrbrn}_{t-1}+\theta_{4} \operatorname{loprc}_{t-1}+\theta_{5} \operatorname{loprn}_{t-1} \\
& +\sum_{i=1}^{m} \alpha_{i} \Delta \operatorname{lrg} d p n_{t-i}+\sum_{i=0}^{n} \gamma_{i} \Delta l r b e_{t-i} \\
& +\sum_{i=0}^{k} \delta_{i} \Delta \operatorname{lrbrn_{t-i}}+\sum_{i=0}^{p} \vartheta_{i} \Delta \operatorname{lrg} d p n_{t-i} \\
& +\sum_{i=0}^{q} \mu_{i} \Delta \operatorname{loprc_{t-i}}+\sum_{i=0}^{r} \pi_{i} \Delta \operatorname{soprn} n_{t-i}+u_{t}
\end{aligned}
$$

Next, we test the null hypothesis $H_{0}: \theta_{1}=\theta_{2}=\ldots=\theta_{5}=0$. The null hypothesis is rejected if the value of the computed F-statistics from the sample is greater than the highest level of the critical value at a given level of significance. If the value is below the lowest level of the critical value corresponding to a level of significance, the null is not rejected. The test results are inconclusive if the computed F-statistic value from the sample is between the lowest-and-highest bands of the critical value. Here, F-distribution critical values calculated by Pesaran and Pesaran (see: Pesaran et al. 1997 or Pesaran et al., 2001) are used, not the conventional critical values of F-distributions. This is because in this case the F-statistics have non-standard distributions unlike conventional F-distributions. 
FMOLS as developed by Phillips and Hansen (1990) has advantages such as correcting for endogeneity and serial correlation effects (Narayan and Narayan, 2004). Mathematical derivation of the FMOLS model is given in Phillips and Hansen (1990) and not discussed here for brevity. Advocated by Stock and Watson (1993), DOLS is employed to estimate long-run equilibria that is corrected for potential simultaneity bias among explanatory variables (Narayan and Narayan, 2004). CCR, developed by Park (1992), is another approach to cointegration that allows OLS to provide asymptotically efficient estimators. To examine the existence of cointegration among variables, we employ both Engle-Granger and Philips-Ouliaris cointegration tests for FMOLS, DOLS and CCR, and Bounds test for the ARDLBT approach.

\section{RESULTS}

The integration order of the variables is examined by employing ADF, PP and KPSS unit root tests with only the intercept, and with the intercept and trend. All results are tabulated in Table II. According to the results, when the trend is not included, ADF, PP, and KPSS provide the same output. For the level of the variables, sample statistics of ADF and $\mathrm{PP}$ are lower than the critical values in absolute terms, meaning the null hypotheses $\left(H_{0}\right.$ : ... has unit root) are not rejected. Moreover, the KPSS sample statistics are greater than critical values for the level of the variables. In other words, the null hypotheses $\left(H_{0}: \ldots\right.$ is stationary) are rejected. However, the null hypotheses of the unit root are rejected for the first difference of the variables as the ADF and PP sample statistics are larger than the critical values. Simultaneously, according to KPSS sample statistics for the first difference of the variables, the null hypothesis of stationarity is not rejected. Therefore, all applied tests conclude the existence of the unit root for the level of all variables, and stationarity for the first difference of variables, meaning our variables are integrated order one, I(1).

With the intercept and trend, tests results are slightly mixed. ADF test results provide the same conclusion. For the level of the variables, ADF sample statistics fail to reject the null hypothesis of unit root.

We reject the null for the first difference of all variables in accordance with sample statistics, which are greater than the critical values in absolute terms. However, the PP test indicates lrgdpn and lrbe to be $\mathrm{I}(0)$ process, while for the remaining variables, the results are analogous to the ADF conclusions. KPSS finds $\operatorname{lrg} d p n$ to be $\mathrm{I}(0)$ process, and lrbe and loprc to be $\mathrm{I}(1)$ process, while test sample statistics are greater than the critical values for lrbrn and loprn at $5 \%$ significance level. This means that both variables are neither $\mathrm{I}(0)$ nor $\mathrm{I}(1)$ process when the trend is included. Fig. 1 indicates a weak data generating process for lrbrn and loprn due to the time trend. To this end, we conclude that all variables employed in our empirical estimations are integrated order one or I(1).

Tab. III reports cointegration test results, namely, the Engle-Granger and Philips-Ouliaris Cointegration test result for FMOLS, DOLS and CCR, and Bounds test results for the ARDLBT approach. All test results indicate the existence of a cointegration relationship at the $1 \%$ significance level. Because we found cointegrated relationship between the variables, we proceed to estimation of the long-run coefficients.

Tab. IV tabulates the long-run estimation results. All models successfully pass residual diagnostic and stability tests. Residuals are integrated of order zero, i.e. I(0) in all models. Except ARDL, model residuals are normally distributed with zero mean and

II: The unit root tests results

\begin{tabular}{|c|c|c|c|c|c|c|c|c|c|}
\hline & \multirow[b]{2}{*}{ Variable } & \multicolumn{4}{|c|}{ The ADF test } & \multicolumn{2}{|c|}{ The PP test } & \multicolumn{2}{|c|}{ The KPSS test } \\
\hline & & Level & k & $\begin{array}{c}\text { First } \\
\text { difference }\end{array}$ & k & Level & $\begin{array}{c}\text { First } \\
\text { difference }\end{array}$ & Level & $\begin{array}{c}\text { First } \\
\text { difference } \\
\end{array}$ \\
\hline \multirow{5}{*}{ Intercept } & $\operatorname{lrg} d p n$ & -1.254 & 3 & $-15.672^{* * *}$ & 2 & -2.108 & $-19.064^{* * *}$ & $0.982^{* * *}$ & 0.181 \\
\hline & lrbe & -1.461 & 3 & $-13.015^{* * *}$ & 2 & -2.222 & $-23.359^{* * *}$ & $0.932^{* * *}$ & 0.205 \\
\hline & lrbrn & -1.835 & 1 & $-11.531^{* * *}$ & 0 & -1.978 & $-13.263^{* * *}$ & $0.832^{* * *}$ & 0.317 \\
\hline & loprc & -1.333 & 2 & $-6.8455^{* * *}$ & 1 & -1.515 & $-5.6081^{* * *}$ & $0.828^{* * *}$ & 0.228 \\
\hline & loprn & -1.300 & 1 & $-5.7735^{* * *}$ & 0 & -1.272 & $-5.7375^{* * *}$ & $0.830^{* * *}$ & 0.299 \\
\hline \multirow{5}{*}{$\begin{array}{l}\text { Intercept } \\
\text { and trend }\end{array}$} & $\operatorname{lrg} d p n$ & -1.811 & 4 & $-15.717^{* * *}$ & 2 & $-7.104^{* * *}$ & $-19.829^{* * *}$ & 0.107 & 0.094 \\
\hline & lrbe & -0.021 & 3 & $-13.254^{* * *}$ & 2 & $-6.101^{* * *}$ & $-26.369^{* * *}$ & $0.253^{* * *}$ & 0.107 \\
\hline & lrbrn & -1.800 & 1 & $-11.602^{* * *}$ & 0 & -2.603 & $-25.347^{* * *}$ & $0.217^{* *}$ & $0.186^{* *}$ \\
\hline & loprc & -1.459 & 2 & $-6.8702^{* * *}$ & 1 & -1.529 & $-5.7116^{* * *}$ & $0.183^{* *}$ & 0.110 \\
\hline & loprn & -0.433 & 0 & $-5.8550^{* * *}$ & 0 & -0.667 & $-5.7719^{* * *}$ & $0.183^{* *}$ & $0.166^{* *}$ \\
\hline
\end{tabular}

Notes: ADF, PP and KPSS denote the Augmented Dickey-Fuller, Phillips-Perron and Kwiatkowski-Phillips-Schmidt-Shin tests respectively. Maximum lag order is set to 10 and optimal lag order (k) is selected based on Schwarz criterion in the ADF test; ***,** and * indicate rejection of the null hypotheses at the $1 \%, 5 \%$ and $10 \%$ significance levels respectively; The critical values are taken from MacKinnon (1996) and Kwiatkowski-Phillips-Schmidt-Shin (1992) for the ADF, PP and KPSS tests respectively. Estimation period: 2000Q1-2015Q2. 
III: Results of the cointegration tests

\begin{tabular}{|c|c|c|c|c|}
\hline & \multicolumn{2}{|c|}{ Engle-Granger Cointegration test } & \multicolumn{2}{|c|}{ Phillips-Ouliaris Cointegration test } \\
\hline & Tau-statistic & $z$-statistic & Tau-statistic & z-statistic \\
\hline FMOLS & $-7.003^{* * *}$ & $-54.553^{* * *}$ & $-7.035^{* * *}$ & $-49.853^{* * *}$ \\
\hline DOLS & $-7.066^{* * *}$ & $-54.328^{* * *}$ & $-7.108^{* * *}$ & $-51.407^{* * *}$ \\
\hline CCR & $-7.065^{* * *}$ & $-54.327^{* * *}$ & $-7.108^{* * *}$ & $-51.407^{* * *}$ \\
\hline \multicolumn{5}{|c|}{ Results of the Bounds test } \\
\hline & \multicolumn{2}{|c|}{$95 \%$ critical bounds } & \multicolumn{2}{|c|}{$99 \%$ critical bounds } \\
\hline & $\mathbf{I}(0)$ & $\mathbf{I}(1)$ & $\mathbf{I}(0)$ & $\mathbf{I}(1)$ \\
\hline$F_{c o}=14.380$ & 2.56 & 3.49 & 3.29 & 4.37 \\
\hline
\end{tabular}

Notes: Dependent variable is $\lg d p n$. the null hypothesis for both tests is: variables are not cointegrated; ***,** and *indicate significance of the coefficients at $1 \%, 5 \%$ and $10 \%$ significance level respectively; Optimal lag length is selected based on the Schwarz criterion taking 4 lags as a maximum; p-values are MacKinnon(1996) p-values for tau-statistic. In the case of 4 regressors, restricted intercept and no trend upper and lower bound Bounds test critical values are taken from Pesaran et al. (2001).

constant variance. As our sample size is relatively larger, the non-normal distribution of residuals in ARDL should not affect robustness of the findings significantly.

Results of the long-run estimations are quite straightforward. All applied methods reveal statistically and economically significant positive contributions of budget expenditures to non-oil sector economic growth. The elasticity coefficient changes between 0.73-0.87 across employed methods, which means a very strong association. Meanwhile, all models also provide the same direction of association from non-transfer budget revenues (as a proxy for tax revenues) to non-oil sector performance. As expected, the impact is negative but surprisingly statistically significant. Remember that we expected negative negligible effect due to oil sector dependency. Only ARDL produces an insignificant and relatively small effect. For the remaining methods, the estimated elasticity of non-oil GDP to non-transfer budget revenues is within -0.49 to -0.35 .

It is surprising that all models conclude with individually and jointly insignificant long-run

IV: Results oflong-run estimations

\begin{tabular}{|c|c|c|c|c|c|}
\hline Variable & OLS & ARDL & FMOLS & DOLS & CCR \\
\hline lrbe & $\begin{array}{c}0.7538^{* * *} \\
(0.087)\end{array}$ & $\begin{array}{c}0.7363^{* * *} \\
(0.109)\end{array}$ & $\begin{array}{c}0.8499^{* * *} \\
(0.068)\end{array}$ & $\begin{array}{c}0.79232^{* * *} \\
(0.089)\end{array}$ & $\begin{array}{c}0.8752^{* * *} \\
(0.089)\end{array}$ \\
\hline lrbrn & $\begin{array}{c}-0.3694^{* * *} \\
(0.127)\end{array}$ & $\begin{array}{c}-0.1152 \\
(0.157)\end{array}$ & $\begin{array}{c}-0.4929^{* * *} \\
(0.105)\end{array}$ & $\begin{array}{c}-0.3587^{* * *} \\
(0.127)\end{array}$ & $\begin{array}{c}-0.3729^{* * *} \\
(0.128)\end{array}$ \\
\hline loprc & $\begin{array}{c}0.078 \\
(0.103)\end{array}$ & $\begin{array}{l}-0.0143 \\
(0.1043)\end{array}$ & $\begin{array}{l}0.0909 \\
(0.082)\end{array}$ & $\begin{array}{l}0.0522 \\
(0.105)\end{array}$ & $\begin{array}{c}-0.0028 \\
(0.104)\end{array}$ \\
\hline loprn & $\begin{array}{l}-0.012 \\
(0.118)\end{array}$ & $\begin{array}{c}-0.2237 \\
(0.137)\end{array}$ & $\begin{array}{c}-0.0891 \\
(0.093)\end{array}$ & $\begin{array}{c}-0.0752 \\
(0.113)\end{array}$ & $\begin{array}{c}-0.1283 \\
(0.114)\end{array}$ \\
\hline $\operatorname{Seas}(1)$ & $\begin{array}{c}-0.1347^{* * *} \\
(0.050)\end{array}$ & $\begin{array}{c}-0.4147^{* * *} \\
(0.145)\end{array}$ & $\begin{array}{c}-0.0768^{*} \\
(0.041)\end{array}$ & $\begin{array}{c}-0.3279^{* * *} \\
(0.071)\end{array}$ & $\begin{array}{c}-0.0754 \\
(0.047)\end{array}$ \\
\hline $\operatorname{Seas}(4)$ & $\begin{array}{c}-0.1703^{* * *} \\
(0.061)\end{array}$ & $\begin{array}{c}-0.1420 \\
(0.123)\end{array}$ & $\begin{array}{c}-0.1979^{* * *} \\
(0.049)\end{array}$ & $\begin{array}{c}-0.0989^{*} \\
(0.058)\end{array}$ & $\begin{array}{c}-0.2207^{* * *} \\
(0.059)\end{array}$ \\
\hline $\mathrm{C}$ & $\begin{array}{c}4.5049^{* * *} \\
(0.386) \\
\end{array}$ & $\begin{array}{c}4.9238^{* * *} \\
(0.424) \\
\end{array}$ & $\begin{array}{c}5.1029^{* * *} \\
(0.323)\end{array}$ & $\begin{array}{c}4.7470^{* * *} \\
(0.364) \\
\end{array}$ & $\begin{array}{c}4.8121^{* * *} \\
(0.372)\end{array}$ \\
\hline \multicolumn{6}{|c|}{ Statistics and Residuals Diagnostics tests results } \\
\hline OLS & \multicolumn{5}{|c|}{$\sigma=0.157368 ; \chi_{S C}^{2}(4)=1.317827[0.2759] ; \chi_{\text {ARCH }}^{2}(4)=2.106905[0.0929] ; \chi_{\text {HETR }}^{2}=1.346725[0.2626] ; J B_{N}=2.166971[0.3384] ; F_{F F}=0.037048[0.8481]$} \\
\hline ARDL & \multicolumn{5}{|c|}{$\sigma=0.103262 ; \chi_{\mathrm{SC}}^{2}(4)=0.626364[0.6465] ; \chi_{\text {ARCH }}^{2}(4)=0.584575[0.6753] ; \chi_{\mathrm{HETR}}^{2}=0.594591[0.8542] ; j B_{N}=14.61617[0.0006] ; F_{F F}=0.533814[0.5963]$} \\
\hline FMOLS & \multicolumn{5}{|c|}{$\sigma=0.156000 ; \chi_{\text {SC }}^{2}(4)=1.230772[0.3100] ; \chi_{\text {ARCH }}^{2}(4)=1.328553[0.2726] ; \chi_{\text {HETR }}^{2}=1.457796[0.2114] ; J B_{N}=2.272790[0.3209]$} \\
\hline DOLS & \multicolumn{5}{|c|}{$\sigma=0.129632 ; \chi_{S C}^{2}(4)=0.304343[0.8737] ; \chi_{\text {ARCH }}^{2}(4)=0.463799[0.7619] ; \chi_{\text {HETR }}^{2}=0.825519[0.5555] ; J B_{N}=1.915126[0.3838]$} \\
\hline CCR & \multicolumn{5}{|c|}{$\sigma=0.157637 ; \chi_{\mathrm{SC}}^{2}(4)=0.855882[0.4966] ; \chi_{\mathrm{ARCH}}^{2}(4)=1.679069[0.1688] ; \chi_{\mathrm{HETR}}^{2}=1.493815[0.1825] ; j B_{N}=3.4665[01767]$} \\
\hline
\end{tabular}

Notes: Dependent variable is lgdpn. $\sigma$ is standard error of regression; $\chi_{\text {SC, }}^{2} \chi_{\text {ARCH }}$ and $\chi_{\text {HETR }}^{2}$ denote chi-squared statistics to test the null hypotheses of no serial correlation, no autoregressive conditioned heteroscedasticity, and no heteroscedasticity in the residuals; $J B_{N}$ indicate statistics to test the null hypotheses of normal distribution; $*, * *$ and *** denote significance level of $10 \%, 5 \%$, and 1 \% levels, respectively; Standard errors are in (). Probabilities are in []. 
V: Test results for short-and long-run causality.

\begin{tabular}{|c|c|c|c|c|c|c|c|}
\hline \multirow[b]{3}{*}{ Dependent variable } & \multicolumn{7}{|c|}{ Source of causation (independent variable) } \\
\hline & & Short-run & & Long-run & & Strong & \\
\hline & $\Delta \operatorname{lrgdpn}$ & Slrbe & $\Delta l r b r n$ & $E C T_{t-1}$ & $\begin{array}{c}E C T_{t-1} \text { and } \\
\Delta l r g d p n\end{array}$ & $\begin{array}{c}E C T_{t-1} \text { and } \\
\Delta l r b e\end{array}$ & $\begin{array}{c}\text { ECT }_{t-1} \text { and } \\
\Delta l r b r n \\
\end{array}$ \\
\hline$\Delta \operatorname{lrgdpn}$ & - & $4.773^{* * *}$ & $2.249^{*}$ & $-0.666^{* * *}$ & - & $7.505^{* * *}$ & $7.696^{* * *}$ \\
\hline Slrbe & $5.393^{* * *}$ & - & $25.39^{* * *}$ & $-0.915^{* * *}$ & $9.567^{* * *}$ & - & $33.015^{* * *}$ \\
\hline
\end{tabular}

Note: The values under Short-run and Strong headings are the Chi-square statistics from the Wald test, while the values under Long-run are speed of adjustment coefficients; ***,**, and * indicate statistical significance at the $1 \%, 5 \%$ and $10 \%$ significance levels respectively; Estimation period: 2000q1-2015q2.

effect of oil-related factors, whereas we expected a major role of those in non-oil sector economic performance. Understanding the explanation for this will require further investigation. On the other hand, empirical estimations reveal strong seasonal features of non-oil GDP.

Tab. V provides short-run and long-run Granger Causality testing results. To discover the direction of causality (unidirectional or bidirectional), we estimated two ECM, first with $\triangle l r g d p n$ and then with $\Delta$ lrbe as the dependent variables.

Test results indicate the existence of short-run bidirectional causality between lrgdpn and lrbe. Simultaneously, non-transfer budget revenues Granger Cause both lrgdpn and lrbe in the short-run. There is long-run association in both models. Moreover, strong (bi)directional causality exists between lrgdpn and lrbe as well as from lrbrn to both variables.

\section{DISCUSSION}

Since the end of 2014, Azerbaijan has been challenged by a sharp decline in oil prices. In light of decreasing oil revenues, the government is forced to consider public expenditures efficiency and broadening the tax base. The Azerbaijan government decided to follow a sharp contractionary budget policy after 10 years of an expansionary trend. Public expenditures were sharply decreased in a budget proposal for 2016. Fiscal policy effectiveness has been a hot topic for discussion, even at the highest level of the government administration.

Regarding public expenditures efficiency, the president of Azerbaijan, Ilham Aliyev emphasized that "we can't allow waste," "we should improve management principles in every state agency and state-owned company," and "we will not give our consent to projects that are not a priority." Given tax related messages, the president stressed that "business people should be responsible and pay taxes in full," "we need to move the informal economic activity into the legal plane" to broaden the tax base, ${ }^{6}$ and "the Ministry of Taxes should try to ensure that taxpayers pay taxes legitimately and in full.". In other words, officials admit to lax tax collection enforcement during the oil boom period and now stricter enforcement will be used to broaden the tax base. All ongoing processes indicate the significance of our research findings for consideration by the current administration, who also declares the development of the non-oil sector as the priority.

For the sake of non-oil sector development, the government must consider the effects of decreasing public expenditures while at the same time increasing tax revenues. Our empirical findings show doubtless strong positive/negative contribution of budget expenditures/tax revenues on non-oil output. In this context, the government must consider approximately $0.73-0.87 \%$ lower non-oil GDP for every $1 \%$ reduction in expenditures and a $1 \%$ increase in tax revenues to lower non-oil GDP by around 0.36-0.49\%, holding other factors fixed. However, there are currently many other factors affecting non-oil sector output negatively. Therefore, the efficiency of government expenditures must be increased to minimize the negative response of non-oil GDP to contractionary fiscal policy in the near future.

4 "Closing speech by Ilham Aliyev at the meeting of the Cabinet of Ministers dedicated to the results of socioeconomic development in 2014 and objectives for 2015", January 10, 2015. Retrieved from: http://en.president.az/articles/14079, 19.05.2016.

5 "Closing speech by Ilham Aliyev at the conference dedicated to results of second year implementation of the State Program on socio-economic development in 2014-2018", January 26, 2016. Retrieved from: http://en.president.az/ articles/17693, 19.05.2016.

6 "Closing speech by Ilham Aliyev at the meeting of the Cabinet of Ministers dedicated to the results of socioeconomic development in the first half of 2015 and objectives for the future", July 13, 2015. Retrieved from: http://en.president. az/articles/16219, 19.05.2016.

7 "Closing speech by Ilham Aliyev at the meeting of the Cabinet of Ministers dedicated to the results of socioeconomic development of 2015 and objectives for the future", January 10, 2016. Retrieved from: http://en.president.az/ articles/17442, 19.05.2016. 


\section{CONCLUSION}

This study investigates the impact of public expenditures and tax revenues on non-oil sector output in the Azerbaijan economy for the period of 2000Q1-2015Q2. For robustness of the results, different cointegration methods are applied to examine long- and short-run association between the variables of interest. All applied cointegration methods - OLS, ARDL, FMOLS, DOLS and CCR produce consistent empirical evidence, demonstrating the robustness of the results.

All methods confirm the existence of cointegrating relationships among the variables. Long-run estimation results indicate a strong positive role of public expenditures in encouraging non-oil sector production, while non-transfer budget revenues (as a proxy for tax revenues) significantly reduce non-oil GDP growth. These findings are theoretically expected and consistent with previous findings in Hasanov (2013a,b), Hasanov and Alirzayev (2012) as well as Aliyev (2014). The inability to find significant long-run impacts of oil-related factors on the non-oil sector is surprising and requires further investigations.

Findings of Granger Causality analysis are also noteworthy to reveal short-run associations. Estimations provide strong bidirectional short-run causality between non-oil GDP and budget expenditures, and the causality from tax revenues to non-oil output and public spending. We also find that our results are in the same line with the similar case countries such as Saudi Arabia and Oman (e.g., Kireyev, 1998; Treichel, 1999), as they indicated in their studies that government should increase public expenditures to preserve non-oil sector. Furthermore, our research work could be more profitable for another resource rich countries by incorporating the variables we used.

\section{REFERENCES}

AFONSO, A. and FURCERI, D. 2010. Government size, composition, volatility and economic growth. European Journal of Political Economy, 26(4): 517-532.

AFONSO, A., SCHUKNECHT, L., and TANZI, V. 2005. Public Sector Efficiency: an International Comparison. Public Choice, 123(3-4): 321-347.

AFONSO, A., SCHUKNECHT, L. and TANZI, V. 2011. Income Distribution Determinants and Public Spending Efficiency. Journal of Economic Inequality, 8(3): 367-389.

ANDERSEN, J. J. AND ASLAKSEN, S. 2008. Constitutions and the Resource Curse. Journal of Development Economics, 87(2): 227-246.

ALESINA, A., CAMPANTE, F. R. and TABELLINI, G. 2008. Why is Fiscal Policy often Procyclical? Journal of the European Economic Association, 6(5): 1006-1036.

ALIYEV, I. 2013. Essays on Natural Resource Impact, Center for Economic Research and Graduate Education. Charles University Prague. Dissertation. [Online]. Available at: http://www.cerge-ei.cz/pdf/ dissertations/2013-aliyev.pdf. [Accessed: 2015, November 1].

AUTY, R. M. 2001.Resource abundance and economic development. OUP Oxford.

BARRO, R. 1991. Economic growth in a cross section of countries. Quarterly Journal of Economics, 106: 407-443.

COORAY, A. 2009. Government Expenditure, Governance and Economic Growth. Comparative Economic Studies, 51(3): 401-418.

DEVERAJAN, S., SWAROOP, V. and ZOU, H. 1996. The composition of public expenditure and economic growth. Journal of Monetary Economics, 1996(37): 313-344.

DIETZ, S., NEUMAYER, E. and DE SOYSA, I. 2007. Corruption, the Resource Curse and Genuine
Saving. Environment and Development Economics, 12(1): 33-53.

ESPINOZA, R. A. and SENHADJI, A. S. 2011. How Strong are Fiscal Multipliers in the GCC?. International Monetary Fund, Working Paper. (61)11.

FOLSTER, S. and HENREKSON, M. 2001. Growth effects of government expenditure and taxation in rich countries. European Economic Review, 45: 1501-1520.

GYLFASON, T. 2004. Natural resources and economic growth: from dependence to diversification'. Centre for Economic Policy Research. Discussion paper 4804.

HASANOV, F. 2013a. The Role of the Fiscal Policy in the Development of the Non-Oil Sector in Azerbaijan. Hazar Raporu, 4: 162-73.

HASANOV, F. 2013b. Dutch disease and the Azerbaijan economy. Communist and Post-Communist Studies, 46: 463-480.

HASANOV, F. and ALIRZAYEV, E. 2012. The government spending, FDIs and the non-oil sector of the oil-exporting economy. The Center for Socio-Economic Research, Qafqaz University. Unpublished manuscript.

HENREKSON M. 1993. Wagner's Law: a Spurious Relationship, Public finance, 48(2): 406-415.

JOHARJI, G. A. and STARR, M. A. 2010. Fiscal policy and growth in Saudi Arabia. Review of Middle East Economics and Finance, 6(3): 24-45.

JOHANSEN, S. and JUSELIUS, K. 1990. Maximum likelihood estimation and inference on cointegration with applications to the demand for money. Oxford Bulletin of Economics and Statistics, 52: 169-210.

JOHANSEN, S. 1988. Statistical analysis of cointegration vectors. Journal of Economic Dynamics and Control, 12: 231-254.

KAMINSKY, G. L., REINHART, C. M. and VÉGH, C. A. 2005. When it rains, it pours: procyclical capital 
flows and macroeconomic policies. In NBER Macroeconomics Annual 2004, Volume 19, MIT Press, 11-82.

KEYNES, J. M. 1936. General Theory of Employment, Interest and Money, London: Macmillan.

KİREYEV, A. 1998. Key Issues Concerning Non-oil Sector Growth. IMF (ed.), Saudi Arabia's Recent Economic Developments and Selected Issues. Washington, DC: IMF, 29-33.

KRUGMAN, P. 1987. The narrow moving band, the Dutch disease, and the competitive consequences of Mrs. Thatcher: Notes on trade in the presence of dynamic scale economies. Journal of development Economics, 27(1-2): 41-55.

KWIATKOWSKI, D., PHILLIPS, P., SCHMIDT, P. and SHIN, Y. 1992. Testing the null hypothesis of stationarity against the alternative of a unit root: How sure are we that economic time series have a unit root? Journal of Econometrics, 54(1-3): 159-178.

LANDAU, D. 1986. Government and Economic Growth in the Less Developed Countries: An Empirical Study of 1960-80. Economic and Culture, 35: 35-76.

MACKINNON, J. 1996. Numerical Distribution Functions for Unit Root and Cointegration Tests. Journal of Applied Econometrics, 11: 601-618.

NARAYAN, S. and NARAYAN, P. K. 2004. Determinants of demand for Fiji's exports: an empirical investigation. The Developing Economies, 42(1): 95-112.

OTENG-ABAYIE, E. F. and FRIMPONG J. M. 2006. Bivariate causality analysis between FDI inflows and economic growth in Ghana. Munich Personal RePEc Archive, University of Munich, Germany.

PARK, J. Y. 1992. Canonical cointegrating regressions. Econometrica, 60: 119-143.

PESARAN, H., SHIN, Y. and SMITH, R. J. 2001. Bound Testing Approaches to the Analysis of Level Relationships. Journal of Applied Econometrics, 16: 289-326.

PESARAN H. M. and SHIN Y. 1999. An autoregressive distributed-lag modelling approach to cointegration analysis. Econometric Society Monographs, 31:371-413.
PESARAN, H. M. and PESARAN, B. 1997. Working with Microfit 4.0: interactive econometric analysis; [Windows version]. Oxford University Press.

PHILLIPS, P. C. B. and HANSEN, B. E. 1990. Statistical inference in instrumental variables regression with I (1) Processes. Review of Economics Studies, 57: 99-125.

SALA-I-MARTIN, X. and SUBRAMANIAN, A. 2003. Addressing the natural resource curse: An illustration from Nigeria. Palgrave Macmillan UK, 61-92.

SACHS, J. D. and WARNER, A. M. 1999. The big push, natural resource booms and growth. Journal of development economics, 59(1): 43-76.

SULAIMAN, D. M. and MUHAMMAD, U. 2010. The Bound Testing Approach for Co-Integration and Causality between Financial Development and Economic Growth in Case of Pakistan. European Journal of Social Sciences, 13: 525-531.

STOCK, J. H. and WATSON, M. 1993. A simple estimator of cointegrating vectors in higher order integrated systems. Econometrica, 61: 783-820.

STURM, M., GURTNER, F. and ALEGRE, J. G. 2009. Fiscal Policy Challenges in Oil-exporting Countries a Review of Key Issues. European Central Bank. Occasional Paper, 104.

WAKEMAN-LINN, J., MATHIEU, P. and VAN SELM, B. 2002. Oil funds in transition economies: Azerbaijan and Kazakhstan. JM Davis, R. Ossowski and A. Fedelino eds, 339-58.

TALVI, E. and VEGH, C. A. 2005. Tax base variability and procyclical fiscal policy in developing countries. Journal of Development economics, 78(1): 156-190.

TORNELL, A. and LANE, P.R. 1999. The voracity effect. American economic review, 22-46.

TREICHEL, V. 1999. Stance of Fiscal Policy and Non-Oil Economic Growth. Oman Beyond the Oil Horizon: Policies Toward Sustainable Growth. Washington, DC: IMF, 26-7.

Khatai Aliyev: xaliyev@qu.edu.az

Bruce Dehning: bdehning@chapman.edu

Orkhan Nadirov: nadirov@fame.utb.cz 